\title{
Bradyrhizobium spp. as attenuators of water deficit stress in runner peanut genotypes based on physiological and gene expression responses
}

\author{
S.L. Brito ${ }^{1}$, A.B. Santos ${ }^{2}$, D.D. Barbosa ${ }^{1}$, P.D. Fernandes ${ }^{3}$, \\ P.I. Fernandes-Júnior ${ }^{4}$ and L.M. Lima ${ }^{5}$ \\ ${ }^{1}$ Programa de Pós-Graduação em Ciências Agrárias, Universidade Estadual \\ da Paraíba, Campina Grande, PB, Brasil \\ ${ }^{2}$ Ciências Biológicas, Universidade Estadual da Paraíba, Campina Grande, \\ PB, Brasil \\ ${ }^{3}$ Departamento de Agroecologia, Universidade Estadual da Paraíba, \\ Campina Grande, PB, Brasil \\ ${ }^{4}$ Embrapa Semiárido, Petrolina, PE, Brasil \\ ${ }^{5}$ Embrapa Algodão, Campina Grande, PB, Brasil
}

Corresponding author: L.M. Lima

E-mail: liziane.lima@embrapa.br

Genet. Mol. Res. 18 (4): gmr18379

Received May 23, 2019

Accepted August 27, 2019

Published October 30, 2019

DOI http://dx.doi.org/10.4238/gmr18379

\begin{abstract}
The peanut plant has high plasticity and great adaptability to adverse conditions, including drought. To mitigate the negative effects of drought on legumes, nitrogen-fixing microorganisms have been investigated in some plant species, such as soybeans and beans. We analyzed the role Bradyrhizobium strains in peanut genotypes subjected to water deficit by means of plant growth, physiological and gene expression analysis. The research was conducted under greenhouse conditions with the runner peanut genotypes (IAC Runner 886, 2012-33 and 2012-47) and two Bradyrhizobium strains (ESA 123 and SEMIA 6144). After 20 days of germination, the water supply was completely interrupted and gas exchange analysis were carried out using an infrared gas analyzer, up to the $10^{\text {th }}$ day of stress. Leaves were collected for the analysis of proline content and the expression of NCED and ERF8 genes. Analyses of plant height (PH), shoot dry mass (SDM), root dry mass $(\mathrm{RDM})$, number of nodules (NN) and nodule weight (NW) also were
\end{abstract}


performed. The peanut shoots inoculated with the Bradyrhizobium strains obtained the best results. The genotypes inoculated with the ESA 123 strain obtained superior responses compared to the nonstressed treatment inoculated with the same bacteria and the stressed control without bacterial inoculation. In the ESA 123 inoculated treatments, the water stressed plants had higher RDM (28.5\% higher, on average), $\mathrm{NN}$ (two fold higher), and gene expression (approximately six and three-fold higher for ERF8 and NCED genes, respectively). The increase in the expression of NCED and ERF8 genes, in the three genotypes inoculated with ESA 123, suggests a key role of this inoculant in the activation of metabolic cascades for plant protection under water deficit.

Key words: Biological nitrogen fixation; ERF8 and NCED genes; Arachis hypogaea; Drought tolerance

\section{INTRODUCTION}

Drought is one of the main factors responsible for negative effects on the development and quality of agricultural production worldwide Hu and Xiong (2014). Water deficiency affects the physiological and nutritional development of plants leading to the reduction of their biomass and growth and, consequently, yield. Drought induces stomatal closure, which limits the exchange of gases and consequently, reduces the photosynthetic rate (Ihuoma and Madramootoo, 2017). Its also causes severe changes in plant metabolism, with damage to cell membranes and to the transport chain, leading to an increase in the production of oxygen-reactive species (Pereira et al., 2016). In order to adapt to these conditions, plants have a controlled metabolic apparatus at a molecular level, by signal transduction cascades, where plant hormones play key roles Müller and Munné-Bosch (2015).

Several genes and transcription factors associated with molecular and physiological changes under drought conditions have been isolated and characterized over the last few years (Chen et al., 2012). In Arabidopsis thaliana the expression of genes under drought conditions, such as AtNCED, has been associated with the synthesis of abscisic acid (ABA). This hormone is involved in the physiological responses to drought, being synthesized in the roots, culminating in the loss of the turgor of the guard cells and stomatal closure (Lata and Prasad, 2011; Umezawa et al., 2011). In addition, ABA triggers the activation of a complex network of triggered transcription factors due to abiotic stresses, especially water deficit (Lata and Prasad, 2011).

Others plant hormones play important roles in stress physiology and interact in a network to reduce the damaging effects to plants. Ethylene is a hormone that mediates the response to abiotic stress in vegetables. Ethylene Responsive Factors (ERFs) represent a family of expressed genes at the end of the cascade of multi-genic expression for ethylene synthesis (Hao et al., 1998). The expression of ERFs tends to be higher in plants under abiotic stresses, which has been found to be related to drought tolerance and salinity in several species Müller and Munné-Bosch (2015). 
The use of rhizobia, bacteria that induce the development of root and/or stem nodules in legumes, has been an alternative to optimize agricultural production through a reduced need for nitrogen fertilizers. In addition to nitrogen fixation, the rhizobium-legume interaction may contribute to host resistance to abiotic stresses such as drought, as has been demonstrated for tropical legumes such as cowpea (Oliveira et al., 2012) and peanut (Melo et al., 2016; Barbosa et al., 2018).

Peanuts (Arachis hypogaea) are one of the world's five most important oilseeds. This species is currently being cropped in over 100 countries, mainly in the tropics (Fletcher and Shi, 2016). Despite its relative tolerance to drought, efforts have been made by plant breeding programs to develop cultivars with the ability to maintain yield under low rainfall conditions (Pereira et al., 2015).

In addition to initiatives to generate new genotypes, research groups have focused on the selection of rhizobia adapted to soil and semiarid climatic conditions. These studies have led to the selection of efficient rhizobia strains both under greenhouse conditions as well as in the field (Sizenando et al., 2016; Santos et al., 2017). Rhizobia can improve legume tolerance to drought as already shown for peanuts (Furlan et al., 2012). The ESA 123 strain of Bradyrhizobium sp. increased peanut yield under various different soil and climate conditions of northeastern Brazil (Sizenando et al., 2016). The inoculation of Bradyrhizobium sp. ESA 123 in upright peanut genotypes, in addition to inducing higher growth and yield, induces reduction of water deficit damages altering the activities of oxidative stress enzymes and increasing the proline concentration in tissues (Barbosa et al., 2018).

Despite these biochemical evidences of drought tolerance induction by inoculation of Bradyrhizobium, gene expression changes in inoculated peanut under water deficit remain unknown. We investigated the possible benefits of the peanut-Bradyrhizobium interaction under drought conditions based on leaf gas exchanges, biometric and NCED and ERF8 gene expression analysis.

\section{MATERIAL AND METHODS}

\section{Plant material and experiment set up}

Three runner genotypes were used: IAC Runner 886 cultivar and the 2012-33 and 2012-47 advanced lineages. All were from Embrapa Peanut Germplasm Active Bank.

The experiment was carried out in a greenhouse at Embrapa, in Campina Grande (07 $13{ }^{\prime} 50^{\prime \prime} \mathrm{S} ; 5^{\circ} 52^{\prime} 52^{\prime \prime} \mathrm{W}, 551 \mathrm{~m}$ asl). Two Bradyrhizobium spp. strains (SEMIA 6144 and ESA 123) were used. The bacteria grew in YEM (Yeast-Extract Mannitol) liquid medium at $28^{\circ} \mathrm{C}$ with constant stirring of $120 \mathrm{rpm}$ for five days (Vincent, 1970). The seeds were superficially disinfected with $96^{\circ}$ ethanol for $30 \mathrm{~s}$, sodium hypochlorite $2.5 \%$ (v/v) for 5 min, followed by 10 washes in autoclaved distilled water (Vincent, 1970) and then planted in pots with capacity for $32 \mathrm{~L}$ of soil and $0.5 \mathrm{~m}$ in diameter. The soil (Fluvic Neosol in loamy-sandy texture) was fertilized with $4 \mathrm{~g}$ of simple superphosphate and $1.5 \mathrm{~g}$ of potassium chloride per pot before planting, according to the technical recommendations for the crop (Cavalcanti, 2008). Four seeds of each genotype were planted per pot, performing the pruning of two plants 10 days after germination. For the inoculation, $1 \mathrm{~mL}$ of bacterial broth was inoculated onto each seed immediately after the planting and a second inoculation 
were conducted 15 days after the sowing. For the second inoculation, the bacterial strains were grown as described and $1 \mathrm{~mL}$ of the bacterial broth was inoculated in the soil, close to the plant stems.

Irrigation was performed daily in order to maintain the moisture content of the soil close to field capacity. Watering was suspended for 10 days after 20 days of germination when the plants reached $50 \%$ of the stomatal closure, a decisive moment for collecting plant material for biometric, biochemical and molecular analyses.

The experimental design used was completely randomized with a factorial arrangement of $3 \times 4 \times 2$, being: three peanut genotypes; $4 \mathrm{~N}$ sources (two Bradyrhizobium sp. inoculants and one source of mineral nitrogen, ammonium nitrate, $1 \mathrm{~g}$ per pot and an absolute control without nitrogen); and two water regimes (control and stress); with six replicates.

\section{Analysis of vegetative growth and physiological traits}

For the vegetative growth data, the following was analyzed: plant height $(\mathrm{PH})$, shoot dry mass (SDM), root dry mass (RDM), number of nodules (NN) and nodule weight (NW).

The measurements of gas exchange were carried out with an Infrared Gas Analyzer (IRGA) apparatus (LCpro, ADC Bio-scientific) to obtain net photosynthesis rates (A, $\mu \mathrm{mol}$ $\mathrm{CO}_{2} \mathrm{~m}^{-2} \cdot \mathrm{s}^{-1}$ ), stomatal conductance ( $\mathrm{gs}$, mol $\mathrm{H}_{2} \mathrm{O} \mathrm{m}{ }^{-2} \cdot \mathrm{s}^{-1}$ ), transpiration $\left(\mathrm{E}, \mathrm{mmol} \mathrm{H}_{2} \mathrm{O} \mathrm{m}{ }^{-2} \cdot \mathrm{s}^{-}\right.$ $\left.{ }^{1}\right)$ and the ratio between the internal and external concentration of $\mathrm{CO}_{2}$ in the leaf $(\mathrm{Ci} / \mathrm{Ca}$, $\mu \mathrm{mol} \mathrm{CO} \mathrm{Col}^{-1}$ air), according to the calculation of the difference between air atmospheric (reference air) and air from the foliar chamber (analyzed air) (Magalhães Filho et al., 2008).

\section{$N C E D$ and $E R F 8$ gene expression}

For the gene expression analysis, leaves were collected after 10 days of stress in liquid nitrogen and stored at $-80^{\circ} \mathrm{C}$. For the extraction of total RNA, $0.1 \mathrm{~g}$ of leaves were macerated in liquid $\mathrm{N}_{2}$ and used with the Invisorb Kit (Invitek) following the manufacturer's recommendations. Next, $1 \mu \mathrm{g}$ of total RNA in each sample was treated with $1 \mathrm{U} / \mu \mathrm{L}$ of DNAse I (BioLab). Purity and concentration were estimated on agarose gel $(0.8 \%)$ and by spectrophotometry. The cDNA synthesis was performed using the ImPromII Reverse Transcription System kit (Promega) from $1 \mu \mathrm{g}$ of total RNA. The oligonucleotides specific for each gene were: NCED (F-ATGATCCACGATTTCGCCAT and R-TCCCAAGCATTCCAAAGATG) and ERF8 (F-GTTTCGGCGGCGGAGCTTCA and RTGCGTTGGCCGAAGGTGTCC). For each RT-qPCR reaction, $6 \mu \mathrm{L}$ do qPCR-SYBR-green mix/Rox (Ludwig), $0.36 \mu \mathrm{L}$ of each primer $(10 \mu \mathrm{M}), 3.5 \mu \mathrm{L}$ of cDNA (diluted 1:3) and water for a final volume of $12 \mu \mathrm{L}$ were used. Amplification conditions were: $95^{\circ} \mathrm{C}$ for 10 min and 40 cycles of $95^{\circ} \mathrm{C}$ for $15 \mathrm{~s}, 60^{\circ} \mathrm{C}$ for $1 \mathrm{~min}$ and finally, $72^{\circ} \mathrm{C}$ for $15 \mathrm{~s}$. The charts, Melt curve and Cqs were automatically generated by the Eco ${ }^{\mathrm{TM}}$ Real-Time PCR System thermal cycler (Illumina) based on the normalization method with reference genes, $\Delta \Delta \mathrm{Cq}$ (Livak and Schmittgen, 2001) and the for analysis of the generated pattern relative quantification was used. The $P P 2 A$ (F-GATCCTTGTGGAGGAGTGGA and RGCGAAACAGTTCGACGAGAT) and Ubiquitina (F-CAACGCTCCATCTTGTCCTT and R- 
TGATCGTCTTTCCCGTAAGC) (Ártico et al., 2014) genes were used as endogenous control.

Aiming to determine the variations in the gene expression was used as control of the reaction a pool of non-stressed treatments.

\section{Proline content determination}

In order to determine the free proline content, the methodology described by (Bates et al., 1973) was used. Initially, it was prepared with heat: $1.25 \mathrm{~g}$ of acid ninhydrin, $30 \mathrm{~mL}$ of glacial acetic acid and $20 \mathrm{~mL}$ of $6 \mathrm{M}$ phosphoric acid, under stirring until it dissolved. The solution was stored at $4^{\circ} \mathrm{C}$ for up to approximately $24 \mathrm{~h}$. A leaf sample $(0.5 \mathrm{~g})$ was homogenized and $3 \mathrm{~mL}$ of $3 \%$ sulfosalicylic acid was added, then the mixture was centrifuged at $2000 \mathrm{x}$ g at room temperature. An aliquot of $500 \mu \mathrm{L}$ of the supernatant was used to react with $500 \mu \mathrm{L}$ of acid ninhydrin and $500 \mu \mathrm{L}$ of glacial acetic acid in a hermetically closed test tube and heated during $1 \mathrm{~h}$ at $100^{\circ} \mathrm{C}$, and then cooled in ice. The reading was performed by adding $1 \mathrm{~mL}$ of toluene to suspend the organic material, which was evaluated in a spectrophotometer at $520 \mathrm{~nm}$.

\section{Statistical analysis}

The data were analyzed using the Sisvar statistical package (v 5.6) applying the variance analysis by the $\mathrm{F}$ test and the comparison of averages by the Tukey Test $(\mathrm{P}<0.05)$.

\section{RESULTS AND DISCUSSION}

Peanut genotypes inoculated with Bradyrhizobium was positively influenced for most of the analyzed variables. There was a decrease in plant height in treatments under water restriction; however, treatments with rhizobia did not differ statistically from the treatment with mineral $\mathrm{N}$ source under the same conditions. For the SDM, there was no statistical difference between the control and stress treatments (Table 1); apparently, the water deficit did not inhibit the development of the plants. We highlight the genotypes inoculated with the ESA 123 strain that showed minimal decrease of the shoot dry mass under water deficit, suggesting that it is a beneficial indication of the symbiosis between plant and bacteria. As to the root dry mass relationship under stress conditions, there was an increase in all genotypes inoculated with the ESA 123 strain, indicating possible benefits of this symbiosis for the genotypes, since the root increase provides a greater depth of the water absorption surface.

Water deficit was not a limiting factor for the increase in the number of nodules in the IAC Runner 886 and 2012-33 genotypes inoculated with the ESA 123 strain, as well as in the 2012-47 genotype with the SEMIA 6144 strain, probably because when the plants were subjected to the water restriction, the nodules were already formed. As to the nodule weight, there was an increase of the same stress conditions in the IAC Runner 886 and 2012-47 genotypes inoculated with the ESA 123 strain.

Plant-growth-promoting rhizobacteria, such as rhizobia, can stimulate root growth, which in addition to the Biological Nitrogen Fixation (BNF) by several other mechanisms. The growth promotion of peanut roots by ESA 123 was already observed (Santos et al., 
2017), even under water stress (Barbosa et al., 2018), indicating a beneficial feature of this strain, in addition to BNF.

Plant inoculation with selected rhizobia can allow plants to overcome drought conditions (Dakora, 2003; Barbosa et al., 2018), as observed for the plants inoculated with ESA 123 in our study, since water stress was not a limiting factor for the nodules maintenance in the genotypes inoculated with the ESA 123 strain, and although some treatments did not promote an increase in the number of nodules under conditions of water deficit, red nodules were observed in the roots, indicating full activity of $\mathrm{N}$-fixation (Cardoso et al., 2009). Although it did not increase plant height and shoot dry mass in the inoculated genotypes, there was no significant difference between control and stress, or severe reductions under stress conditions, once again demonstrating the importance of this symbiosis.

Table 1. Plant height (PH), shoot dry mass (SDM), root dry mass (RDM), number of nodules (NN) and nodule weight $(\mathrm{NW})$, for three peanut genotypes inoculated with Bradyrhizobium spp. under water deficit conditions.

\begin{tabular}{|c|c|c|c|c|c|c|c|c|c|c|}
\hline \multicolumn{11}{|c|}{ IAC RUNNER 886} \\
\hline \multirow[t]{2}{*}{ Source of $\mathbf{N}$} & \multicolumn{2}{|c|}{ PH $\left(\mathrm{cm} \mathrm{plant}^{-1}\right)$} & \multicolumn{2}{|c|}{ SDM $\left(\right.$ g plant $\left.^{-1}\right)$} & \multicolumn{2}{|c|}{ RDM $\left(\right.$ g plant $\left.^{-1}\right)$} & \multicolumn{2}{|c|}{ NN (nodules plant $\left.{ }^{-1}\right)$} & \multicolumn{2}{|c|}{ NW (mg plant $\left.{ }^{-1}\right)$} \\
\hline & NS & WS & NS & WS & NS & WS & NS & WS & NS & WS \\
\hline SEMIA 6144 & $14.90 \mathrm{Aa}$ & $6.83 \mathrm{Bb}$ & $1.21 \mathrm{Aa}$ & $1.02 \mathrm{Aa}$ & $0.36 \mathrm{Ab}$ & $0.35 \mathrm{Bb}$ & $22.00 \mathrm{Aa}$ & $4.66 \mathrm{Bb}$ & $14.0 \mathrm{Aa}$ & $4.3 \mathrm{Bb}$ \\
\hline ESA 123 & $12.33 \mathrm{Aa}$ & $12.16 \mathrm{Ba}$ & $1.28 \mathrm{Aa}$ & $1.23 \mathrm{Aa}$ & $0.34 \mathrm{Ab}$ & $0.45 \mathrm{Ba}$ & $4.66 \mathrm{Ab}$ & $14.33 \mathrm{Ba}$ & $3.6 \mathrm{Bb}$ & 7.0Ba \\
\hline WN & $13.46 \mathrm{Aa}$ & $11.20 \mathrm{Ba}$ & $1.25 \mathrm{Aa}$ & $1.23 \mathrm{Aa}$ & $0.26 \mathrm{Ab}$ & $0.35 \mathrm{Bb}$ & - & - & - & - \\
\hline $\mathrm{NN}$ & $13.46 \mathrm{Aa}$ & $9.93 \mathrm{Bab}$ & $0.82 \mathrm{Ab}$ & $1.04 \mathrm{Aa}$ & $0.65 \mathrm{Aa}$ & $0.32 \mathrm{Bc}$ & - & - & - & - \\
\hline \multicolumn{11}{|c|}{$2012-33$} \\
\hline SEMIA 6144 & $12.23 \mathrm{Aab}$ & $10.23 \mathrm{Bab}$ & $1.24 \mathrm{Aa}$ & $0.95 \mathrm{Aa}$ & $0.31 \mathrm{Aa}$ & $0.31 \mathrm{Bc}$ & $19.33 \mathrm{Aa}$ & $18.00 \mathrm{Aa}$ & $16.0 \mathrm{Aa}$ & $12.0 \mathrm{Ba}$ \\
\hline ESA 123 & $15.23 \mathrm{Aa}$ & $12.76 \mathrm{Ba}$ & $1.17 \mathrm{Aa}$ & $1.16 \mathrm{Aa}$ & $0.36 \mathrm{Aa}$ & $0.47 \mathrm{Ba}$ & $12.66 \mathrm{Ab}$ & $20.66 \mathrm{Aa}$ & $170.0 \mathrm{Aa}$ & $14.0 \mathrm{Ba}$ \\
\hline $\mathrm{WN}$ & $12.66 \mathrm{Aab}$ & $11.63 \mathrm{Ba}$ & $1.02 \mathrm{Aa}$ & $1.13 \mathrm{Aa}$ & $0.36 \mathrm{Aa}$ & $0.33 \mathrm{Bc}$ & - & - & - & - \\
\hline $\mathrm{NN}$ & $10.90 \mathrm{Ab}$ & $7.96 \mathrm{Bb}$ & $1.04 \mathrm{Aa}$ & $0.91 \mathrm{Aa}$ & $0.30 \mathrm{Aa}$ & $0.41 \mathrm{Bb}$ & - & - & - & - \\
\hline \multicolumn{11}{|c|}{$2012-47$} \\
\hline SEMIA 6144 & $11.63 \mathrm{Ab}$ & $6.83 \mathrm{Bb}$ & $1.14 \mathrm{Aa}$ & $1.07 \mathrm{Aa}$ & $0.34 \mathrm{Aa}$ & $0.50 \mathrm{Ba}$ & $15.66 \mathrm{Aa}$ & $32.33 \mathrm{Ba}$ & $18.0 \mathrm{Aa}$ & $10.0 \mathrm{Bb}$ \\
\hline ESA 123 & $12.10 \mathrm{Aab}$ & $10.20 \mathrm{Bab}$ & $1.09 \mathrm{Aa}$ & $0.99 \mathrm{Aa}$ & $0.40 \mathrm{Aa}$ & $0.49 \mathrm{Ba}$ & $18.33 \mathrm{Aa}$ & $13.66 \mathrm{Bb}$ & $16.0 \mathrm{Ab}$ & $18.0 \mathrm{Ba}$ \\
\hline WN & $10.40 \mathrm{Ab}$ & $10.33 \mathrm{Ba}$ & $1.12 \mathrm{Aa}$ & $1.01 \mathrm{Aa}$ & $0.38 \mathrm{Aa}$ & $0.49 \mathrm{Ba}$ & - & - & - & - \\
\hline NN & $15.46 \mathrm{Aa}$ & 7.43Bab & $1.06 \mathrm{Aa}$ & $1.08 \mathrm{Aa}$ & $0.36 \mathrm{Aa}$ & $0.40 \mathrm{Ba}$ & - & - & - & - \\
\hline
\end{tabular}

NS = No Stress, WS = Water Stress. Upper case letters in the column for genotype within the water regime $($ Tukey, $\mathrm{P}<$ 0.05) and lower case letters in the column comparing averages in the line of treatments with nitrogen source within the water regime (Tukey, $\mathrm{P}<0.05$ ).

The ESA 123 strain probably mitigated the effects of water deficit, especially in the IAC Runner 886 and 2012-33 genotypes, since it provided an increase in root dry mass and lower reduction parameters in the plant height and shoot dry mass variables under stress conditions. Similar results (for shoots and roots) were observed to the inoculation of ESA 123 to upright peanut genotypes under drought (Barbosa et al., 2018), highlighting the efficiency of ESA 123 in such divergent peanut genotypes under drought.

Regarding the leaf gas exchanges, we observed a decrease in net photosynthesis, stomatal conductance and transpiration in all genotypes investigated under water deficit conditions, with the exception of the IAC Runner 886 in the treatment with ammonium nitrate (Figure 1). Rhizobia inoculation, specially the strain ESA 123 induced increases in the net photosynthesis rate and stomatal conductance. Stomatal activity is essential in physiological processes, being the main means of gaseous exchanges between the atmosphere and the interior of the photosynthetic machinery (Singh and Reddy, 2011). 
Furlan et al. (2017) reported that a decrease in photosynthesis may restrict the supply of carbon to the nodules; this fact may explain the decrease in nodule weight in some of the genotypes investigated. A high similarity in the $C i, A$ and $E$ was also observed, a fact expected because, as the water availability in the soil is reduced, the stomatal closure is induced, consequently there is a reduction in photosynthesis, limiting the entry of $\mathrm{CO}_{2}$, as well as a reduction in transpiration, because the main means of water loss is through the stomata (Larcher, 2006).

An increase in the expression of the ERF8 and NCED genes was observed in the genotypes inoculated with the ESA 123 strain under conditions of water deficit (Figure 2).
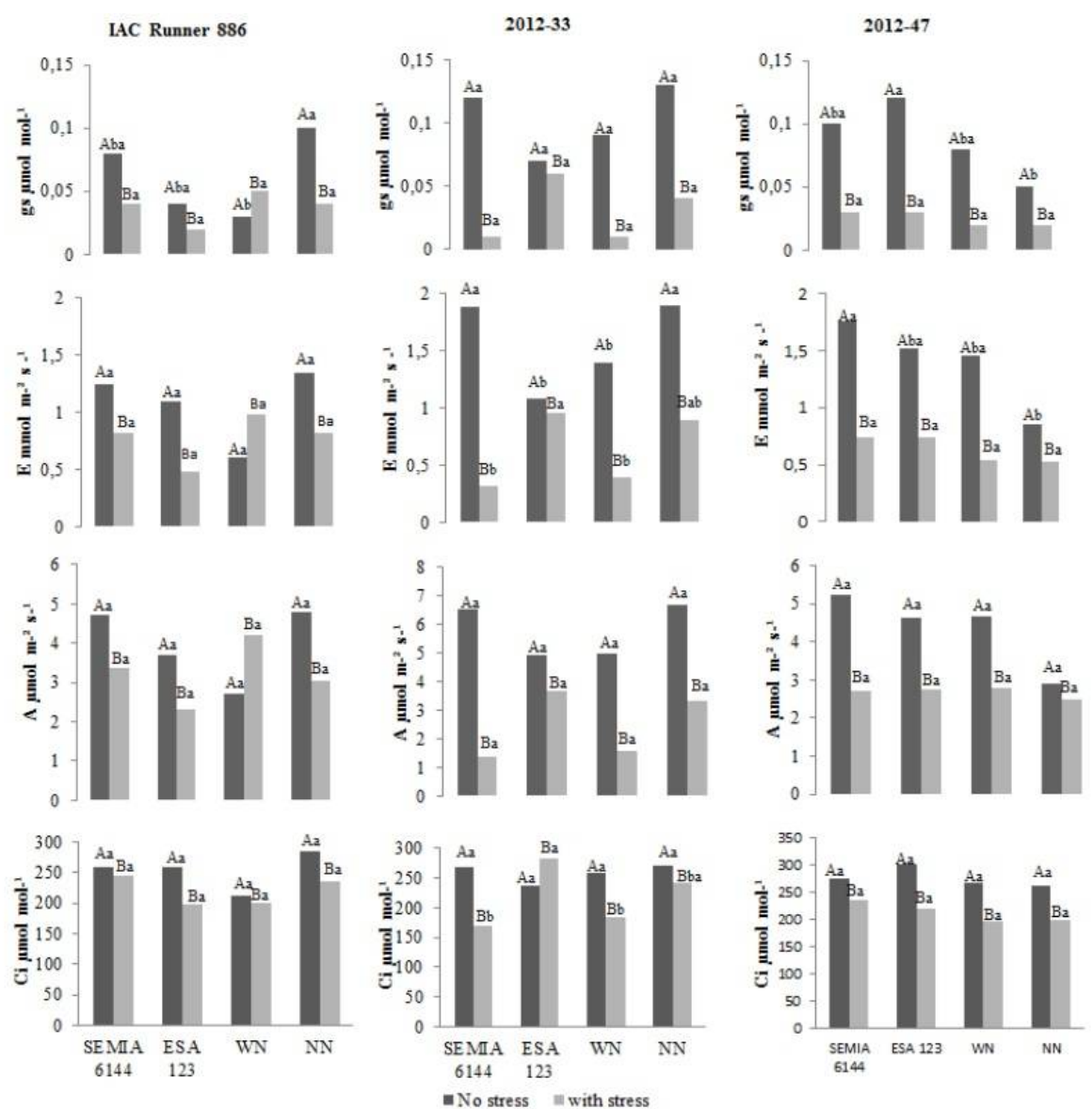

Figure 1. Stomatic conductance $(g s)$, transpiration $(E)$, net photosynthesis $(A)$, internal $\mathrm{CO}_{2}$ concentration $(C i)$ in three peanut genotypes inoculated with Bradyrhizobium spp. under water deficit conditions. Upper case letters comparing the averages between the water regimes; and lower case letters comparing treatments of the same water regime (Tukey Test, $\mathrm{P}<0.05$ ).

On the other hand, the genotypes inoculated with SEMIA 6144, presented no increase in the expression of the ERF8 and NCED genes under water deficit conditions, except for the IAC Runner 886 genotype for the NCED gene. Plants submitted to abiotic stresses, such as salinity, drought and cold stress, activate various defense components, 
either ABA-dependent or ABA-independent pathways, which interact or converge to activate the genes involved in the stress (Roychoudhury et al., 2013; Yoshida et al., 2014). Therefore, the genes that participate in the ABA biosynthetic pathway tend to increase their expression (Zhang et al., 2008; Pan et al., 2010), this is a natural plant response. Despite already having been described in the literature what the ERF8 and NCED genes are responsive to water stress in plants (Cheng et al., 2013; Souza et al., 2016), the mechanism by which these bacteria induce the expression of these genes is unknown.

Among some of the factors that act on the ABA independent pathway, there is the ERF, which belongs to a family of transcription factors know to activate the expression of genes from their binding to specific sequences of the DRE (Dehydration Responsive Element) element in the promoter of abiotic stress-specific genes (salinity, drought and heat) that integrate the ethylene signals (Mizoi et al., 2012; Cheng et al., 2013). Ethylene is an important hormone in several physiological processes of plants, acting as an inducer of responses related to different stresses, such as the attack of pathogens, UV radiation, extreme temperature and drought (O’Donnell et al., 1996; Penninckx et al., 1996).
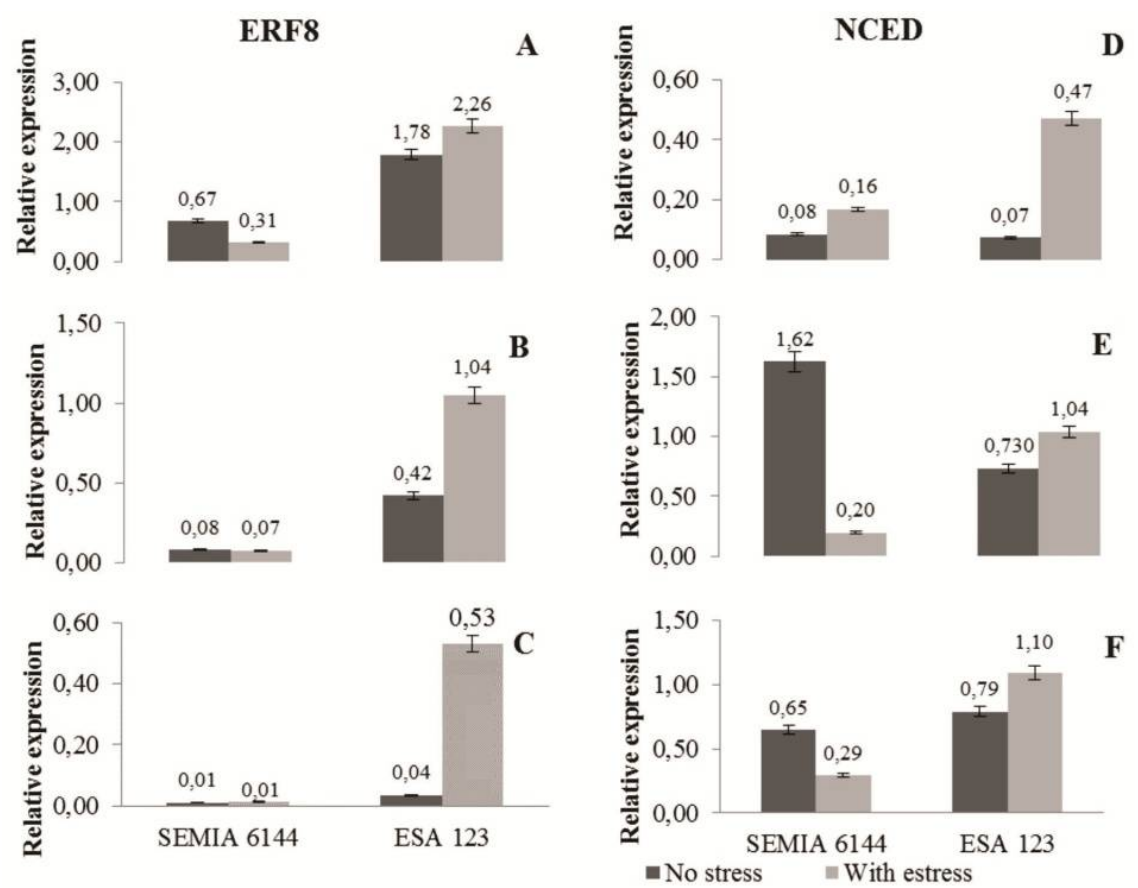

Figure 2. Relative quantification of $E R F 8$ and $N C E D$ gene expression in peanut genotypes inoculated with Bradyrhizobium and under water deficit conditions. A and D- IAC Runner 886; B and E- 2012-33; C and F2012-47.

Cheng et al. (2013) analyzed the ERF1 gene expression in Arabidopsis and confirmed that many stress-inducible genes are potentially downstream of $E R F 1$, including RD29B, COR47 and LEA4-5, among others. Among the 1,156 ERF1-regulated genes, 46 presented expression under drought and 61 under salinity. In this study, ERF8 presented high expression during water deficit in A. hypogaea cultivars, suggesting its importance in 
the interaction with the DRE elements and in the tolerance and acclimatization processes of the plant (Dang et al., 2012).

Li et al. (2015) reported that AP2 and ERF proteins are part of important factors in plant transcription, regulating various development pathways and response to stress. The increase in the expression of genes of the ERF family in Arabidopsis and tobacco provides greater resistance to biotic and abiotic stresses (Park et al., 2001; Berrocal-Lobo et al., 2002; Pan et al., 2010).

Greater biosynthesis of $\mathrm{ABA}$ is correlated with an increase in the expression of NCED family members in leaf and root tissues (Zhang et al., 2008), given that this gene participates at the end of ABA metabolic cascade. Wan and $\mathrm{Li}$ (2006) reported that the ectopic expression of AhNCEDl in peanuts (A. hypogaea L.) was correlated to the accumulation of ABA in tissues in response to water deficit, which increased plant tolerance to stress. ABA, among other functions, is a hormone related to stomatal opening and closure. In this study, we can correlate the increase of NCED gene expression with the closure the stomata in the three genotypes investigated, when inoculated with ESA 123. The beneficial action of the inoculant in activating plant defense mechanisms to water deficit is clear; however, these mechanisms still need to be better elucidated.

It is important to emphasize that studies regarding gene expression in peanut genotypes inoculated with Bradyrhizobium under conditions of water deficit have not been reported. It was observed that the genotypes inoculated with ESA 123 obtained better responses under water deficit conditions, since the increase in NCED and ERF8 gene expression are closely related to the plant signaling and response capacity to stress conditions.

The increase of NCED and ERF8 gene expression observed due to ESA 123 inoculation, is opposite to the reduction of oxidative stress proteins activity recently observed by Barbosa et al. (2008) studying the same isolate inoculated in different peanut genotypes. These complementary results indicate that the inoculation of ESA 123 allow peanut plants to show earlier stress tolerance mechanisms, triggered by NCED and ERF 8 transcripts, avoiding the accumulation of oxygen-reactive species.

Sankar et al. (2014), in studies with peanuts, observed proline accumulation in stressed plants and emphasized that the accumulation of proline under these conditions suggests an adaptation of the plants to overcome the stress conditions. Increased levels of ABA were already related to increased proline content in Phaseolus vulgaris (Mackay et al., 1990) and Arabidopsis thaliana (Verslues and Elizabeth, 2006). The accumulation of ABA, suggested by the increase in $N C E D$ gene expression and decrease in stomatal conductance in this study, may have favored the increase in proline content (Figure 3). The increase in proline content, along with increased NCED gene expression for all genotypes, as well as the ERF8 gene, favored better responses in acclimatization of plants under water deficit conditions, principally when inoculated with the Bradyrhizobium sp. ESA 123. This strain may have mitigated the effects of stress and contributed to the responses of plants to the water deficit.

Despite the availability of research data concerning gene expression of peanut genotypes under drought (Pruthvi et al., 2013) and the mitigation effects of rhizobial inoculation to drought induced damages (Barbosa et al., 2018), there are no data available relating gene expression of inoculated plants under drought conditions. This is the first 
comprehensive study evaluating the expression of NCED and ERF8 genes in inoculated peanuts submitted to drought conditions.

IAC Runner 886

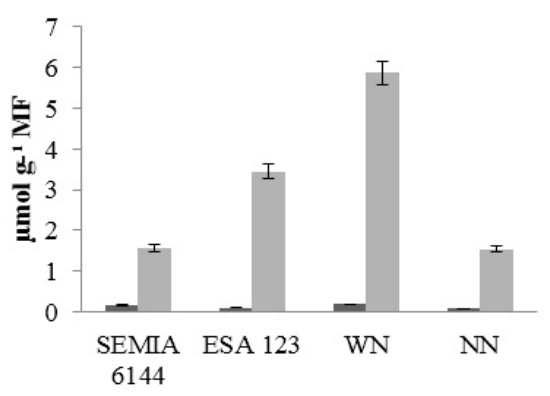

2012-33

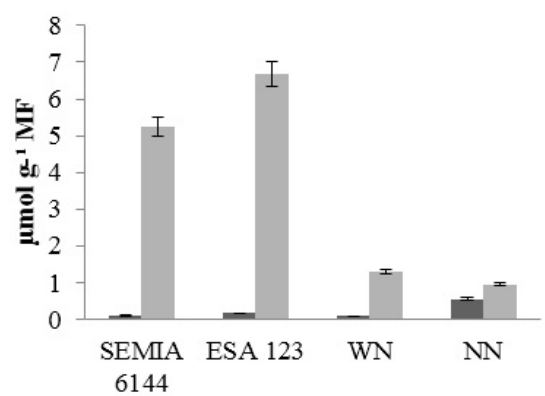

2012-47

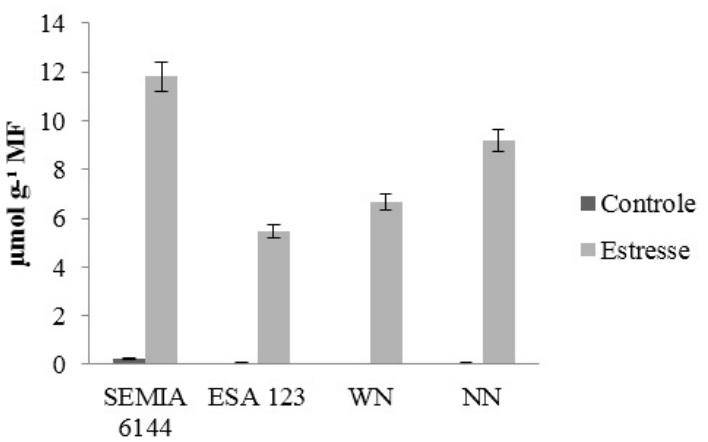

Figure 3. Proline content in peanut genotypes inoculated with Bradyrhizobium under water deficit conditions. $\mathrm{WN}$ - with nitrogen; NN- no nitrogen.

\section{CONCLUSIONS}

Plants inoculated with Bradyrhizobium strains were able to mitigate the effects of water stress. However, genotypes inoculated with ESA 123 were superior under conditions of water deficit based on the molecular and biometric analysis (RMS and NN). However, it will be useful to conduct more interaction studies between genotypes and strains in view of the benefits that these interaction may provide, especially under water deficit conditions.

Among the plant and bacterial germplasms assessed, the IAC Runner 886 genotype was the most responsive to inoculation and ESA 123 was the best strain for the peanut genotypes under water deficit.

\section{ACKNOWLEDGMENTS}

Acknowledgments are due to the Brazilian Agricultural Research Corporation (Embrapa, 03.16.05.016.00.00) for financial support; to Coordination of Improvement of 
Water stress in peanuts inoculated with Bradyrhizobium spp.

Higher Education Personnel (CAPES) and to Brazilian Council for Scientific and Technological Development (CNPq) for providing a scholarship. We would also like to thank Dr. Tais de Moraes Falleiro Suassuna (Embrapa) for supplying seeds.

\title{
CONFLICTS OF INTEREST
}

\author{
The authors declare no conflict of interest.
}

\section{REFERENCES}

Ártico S, Ribeiro-Alves M and Oliveira-Neto OB (2014). Transcriptome analysis of Gossypium hirsutum flower buds infested by cotton boll weevil (Anthonomus grandis) larvae. BMC Genomics. 15: 854.

Barbosa DD, Brito SL, Fernandes PD, Fernandes-Júnior PI, et al. (2018). Can Bradyrhizobium strains inoculation reduce water deficit effects on peanuts? World J. Microbiol. Biotechnol. 34: 87.

Bates L, Waldren RP and Teare ID (1973). Rapid determination of free proline for water-stress studies. Plant Soil. 39(1): 205-207.

Berrocal-Lobo M, Miolina A and Solano R (2002). Constitutive expression of Ethylene-Response-Factor1 in Arabidopsis confer resistance to several necrotrophic fungi. Plant J. 29(1): 23-32.

Cardoso JD, Gomes DF, Goes KCGP, Fonseca NDS, et al. (2009). Relationship between total nodulation and nodulation at the root crown of peanut, soybean and common bean plants. Soil Biol. Biochem. 41: 1760-1763.

Cavalcanti FJA (2008). Fertilization recommendations for the State of Pernambuco: second ed. Recife: Instituto Agronômico de Pernambuco, 212p.

Chen N, Yang Q, Su M, Pan L, et al. (2012). Cloning of six ERF family transcription factor genes from peanut and analysis of their expression during abiotic stress. Plant Mol. Biol. 30(6): 1415-1425.

Cheng MC, Liao PM, Kuo WW and Lin TP (2013). The Arabidopsis ETHYLENE RESPONSE FACTOR ${ }_{1}$ regulates abiotic stress-responsive gene expression by binding to different cis-acting elements in response to different stress signals. Plant Physiol. 162(3): 1566-1583.

Dakora FD (2003). Defining new roles for plant and rhizobial molecules in sole and mixed plant cultures involving symbiotic legumes. New Phytol. 158: 39-49.

Dang PM, Chen CY and Holbrook CC (2012). Identification of genes encoding drought-induced transcription factors in peanut (Arachis hypogaea L.). J. Mol. Biochem. 1: 196-205.

Fletcher SM and Shi Z (2016). An overview of world peanut markets. In: Stalker HT and Wilson RF (ed) Peanuts Genetics, Processing, and Utilization. AOCS Press: pp 267-387.

Furlan AL, Bianucci E, Castro S and Dietz KJ (2017). Metabolic features involved in drought stress tolerance mechanisms in peanut nodules and their contribution to biological nitrogen fixation. Plant Sci. 263: 12-22.

Furlan A, Llanes A, Luna V and Castro S (2012). Physiological and biochemical responses to drought stress and subsequent rehydration in the symbiotic association peanut-Bradyrhizobium sp. ISRN Agron. 2012: 318083.

Hao D, Ohme-Takagi M and Sarai A (1998). Unique mode of GCC box recognition by the DNA-binding domain of ethylene-responsive element-binding (ERF domain) in plant. J. Biol. Chem. 273(41): 26857-26861.

$\mathrm{Hu} \mathrm{H}$ and Xiong L (2014). Genetic engineering and breeding of drought-resistant crops. Annu. Rev. Plant Biol. 65: 715741.

Ihuoma SO and Madramootoo CA (2017). Recent advances in crop water stress detection. Comput. Electron. Agr. 141: 267-275.

Larcher W (2006). Plant ecophysiology. 2 ed. São Carlos: Rima Arts and Texts. 550 p.

Lata C and Prasad M (2011). Role of DREBs in regulation of abiotic stress responses in plants. J. Exp. Bot. 62(14): 4731-4748.

Li MY, Xu ZS, Huang Y, Tian C, et al. (2015). Genome-wide analysis of AP2/ERF transcription factors in carrot (Daucus carota L.) reveals evolution and expression profiles under abiotic stress. Mol. Gen. Genomics. 290(6): 2049-2061.

Livak KJ and Schmittgen TD (2001). Analysis of relative gene expression data using real-time quantitative PCR and the 2 (-Delta Delta C(T)) method. Methods. 25(4): 402-408.

Mackay CE, Hall JC, Hofstra G and Fletcher RA (1990). Uniconazole-induced changes in abscisic acid, total aminoacids, and proline in Phaseolus vulgaris. Pest. Biochem. Physiol. 37(1): 74-82.

Magalhães Filho JR, Amaral LR, Machado DFSP, Medina CL, et al. (2008). Water deficiency, gas exchange and root growth in Valencia orange tree on two types of rootstock. Bragantia. 67(1): 75-88.

Melo EBS, Lima LM, Fernandes-Junior PI, Aidar ST, et al. (2016). Nodulation, gas exchanges and production of peanut cultivated with Bradyrhizobium in soils with different textures. Comunicata Scientiae. 7(2): 160-166. 
Mizoi J, Shinozaki K and Yamaguchi-Shinozak K (2012). AP2/ERF family transcription factors in plant abiotic stress responses. Biochim. Biophys. Acta. 1819(2): 86-96.

Müller M and Munné-Bosch S (2015). Ethylene response factors: A key regulatory hub in hormone and stress signaling. Plant Physiol. 169: 32-41.

O'Donnell PJ, Calvert C, Atzorn R, Wasternack C, et al. (1996). Ethylene as a signal mediating the wound response of tomato plants. Science. 13(274): 1914-1917.

Oliveira MT, Benko-Iseppon AM, Kido EA and Santos MG (2012). Leaf photosynthetic metabolism and $\mathrm{N}_{2}$ fixation at the flowering stage in three genotypes of cowpea [Vigna unguiculate (L.) Walp.]. J. Agric. Sci. 4(2): 245-256.

Pan IC, Li CW, Su RC, Cheng CP, et al. (2010). Ectopic expression of an EAR motif deletion mutant of SIERF3 enhances tolerance to salt stress and Ralstonia solanacearum in tomato. Planta. 232(5): 1075-1086.

Park JM, Park CJ, Lee SB, Ham BK, et al. (2001). Overexpression of the tobacco Tsi1 gene encoding an EREBP/AP2type transcription factor enhances resistance against pathogen attack and osmotic stress in tobacco. Plant Cell. 13(5): 1035-1046.

Penninckx IA, Eggermont K, Terras FR, Thomma BP, et al. (1996). Pathogen-induced systemic activation of a plant defensin gene in Arabidopsis follows a salicylic acid-independent pathway. Plant Cell. 8(12): 2309-2323.

Pereira JWL, Silva ECA, Luz LN, Nogueira RJMC, et al. (2015). Cluster analysis to select peanut drought tolerance lines. Aust. J. Crop Sci. 9(11): 1095-1105.

Pereira JWL, Albuquerque MB, Filho PAM, Nogueira RJMC, et al. (2016). Assessment of drought tolerance of peanut cultivars based on physiological and yield traits in a semiarid environment. Agricult. Water Manag. 166: 70-76.

Pruthvi V, Rama N, Govind G and Nataraja KN (2013). Expression analysis of drought stress specific genes in peanut (Arachis hypogaea L.). Physiol. Mol. Biol. Plants. 19(2): 277-281.

Roychoudhury A, Paul S and Basu S (2013). Cross-talk between abscisic acid-dependent and abscisic acid-independent pathways during abiotic stress. Plant Cell Rep. 32(7): 985-1006.

Sankar B, Gopinathan P, Karthishwaran K and Somasundaram R (2014). Biochemical content variation in Arachis hypogaea under drought stress with or without paclobutrazol and abscisic acid. J. Ecobiotechnol. 6: 9-14.

Santos JWM, Silva JF, Ferreira TDS, Dias MAM, et al. (2017). Molecular and symbiotic characterization of peanut bradyrhizobia from the semi-arid region of Brazil. Appl. Soil Ecol. 121: 177-184.

Singh SK and Reddy KJ (2011). Regulation of photosynthesis, fluorescence, stomatal conductance and water-use efficiency of cowpea (Vigna unguiculata [L.] Walp.) under drought. J. Photoch. Photobiol. 105(1): 40-50.

Sizenando CIT, Ramos JPC, Fernandes-Junior PI, Lima LM, et al. (2016). Agronomic efficiency of Bradyrhizobium in peanut under different environments in Brazilian Northeast. Afr. J. Agric. Res. 11(37): 3482-3487.

Souza AMS, Batista VGL, Pinheiro MPN, Suassuna JF, et al. (2016). Expression of NCED gene in colored cotton genotypes subjected to water stress. Braz. J. Agric. Eng. 20(8): 692-696.

Umezawa T, Hirayama T, Kuromori T and Chinosaki K (2011). Chapter 6 - The Regulatory networks of plant responses to abscisic acid. In: Turkan, I. (Ed), Advances in Botanical Research, Academic Press. v. 57, p. 201-248.

Verslues PE and Elizabeth AB (2006). Role of abscisic acid (ABA) and Arabidopsis thaliana ABA-insensitive loci in low water potential-induced ABA and proline accumulation. J. Exp. Bot. 57(1): 201-212.

Vincent JM (1970). A manual for the practical study of root nodule bacteria. Oxford: Blackkwell Science Publication. $164 p$.

Wan XR and Li L (2006). Regulation of ABA level and water-stress tolerance of Arabidopsis by ectopic expression of a peanut 9-cis-epoxycarotenoide dioxygenase gene. Biochem. Biophys. Res. Commun. 347(4): 1030-1038

Yoshida T, Mogami J and Yamaguchi-Shinozaki K (2014). ABA-dependent and ABA-independent signaling in response to osmotic stress in plants. Curr. Opin. Plant Biol. 21: 133-139.

Zhang Y, Lu JYS, Cai J and Guo Z (2008). Overexpressing SgNCED1 in tobacco increases ABA level, antioxidant enzyme activities, and stress tolerance. J. Plant Growth Regul. 27(2): 151-158. 